University of Nebraska - Lincoln

DigitalCommons@University of Nebraska - Lincoln

Faculty Publications, Classics and Religious

Studies Department

2008

\title{
Sample Editions of the Oxford Hebrew Bible: Deuteronomy 32:1-9, 1 Kings 11:1-8, and Jeremiah 27:1-10 (34 G)
}

\author{
Sidnie White Crawford \\ University of Nebraska-Lincoln, scrawford1@unl.edu \\ Jan Joosten \\ Université de Strasbourg \\ Eugene Ulrich \\ University of Notre Dame
}

Follow this and additional works at: https://digitalcommons.unl.edu/classicsfacpub

Part of the Classics Commons

Crawford, Sidnie White; Joosten, Jan; and Ulrich, Eugene, "Sample Editions of the Oxford Hebrew Bible: Deuteronomy 32:1-9, 1 Kings 11:1-8, and Jeremiah 27:1-10 (34 G)" (2008). Faculty Publications, Classics and Religious Studies Department. 98.

https://digitalcommons.unl.edu/classicsfacpub/98

This Article is brought to you for free and open access by the Classics and Religious Studies at DigitalCommons@University of Nebraska - Lincoln. It has been accepted for inclusion in Faculty Publications, Classics and Religious Studies Department by an authorized administrator of DigitalCommons@University of Nebraska - Lincoln. 


\title{
Sample Editions of the Oxford Hebrew Bible: Deuteronomy 32:1-9, 1 Kings 11:1-8, and Jeremiah 27:1-10 (34 G)
}

\author{
Sidnie White Crawford ${ }^{\mathrm{a}}$, Jan Joosten ${ }^{\mathrm{b}}$, and Eugene Ulrich \\ a) Lincoln, Nebraska \\ b) Strasbourg \\ c) Notre Dame, Indiana
}

\begin{abstract}
For abstract, see the accompanying article by Ronald Hendel.

Keywords

For keywords, see the accompanying article by Ronald Hendel.
\end{abstract}

The following sample editions illustrate the theory and method of the Oxford Hebrew Bible. The Deuteronomy sample, edited by Sidnie White Crawford, concerns a text with one ancient edition, while the Kings sample, edited by Jan Joosten, and the Jeremiah sample, edited by Eugene Ulrich, concern texts with two ancient editions. The arguments that justify the editorial decisions are presented in the apparatuses and text-critical commentaries. (The detailed introductory chapters are not included.) The critical texts, following the conventions discussed in the previous article, contain the following sigla: a superlinear circlet to indicate an entry in the apparatus where the critical text reproduces the copy-text, and a superlinear squarelet to indicate an entry in the apparatus where the critical text differs from the copy-text. Readings in the critical text that differ from the copy-text lack the vocalization and accents of the copy-text. For the sigla and abbreviations used in the apparatus, see the OHB website (http://ohb.berkeley.edu). 


\section{Deuteronomy 32:1-9}

In the case of the book of Deuteronomy, we are fortunate to have a great deal of manuscript evidence from the ancient period. First, there are three complete ancient witnesses to the text of Deuteronomy: the Masoretic Text (M), the Septuagint $(\mathrm{G})$, and the Samaritan Pentateuch (SP), along with their daughter versions. Second, there is now a wealth of new, fragmentary manuscript evidence for Deuteronomy from the Dead Sea Scrolls. These include thirty or thirty-one Hebrew manuscripts from the Qumran caves, one from the finds in Wadi Murabba'at, one from Nahal Hever/Wadi Seiyal, and one from Masada. There is also one Greek Deuteronomy manuscript from Qumran, for a total of thirty-four or thirty-five. ${ }^{1}$

Lengthy Deuteronomy passages also appear in many "non-biblical" texts from the Dead Sea Scrolls, most notably in the Temple Scroll and 4QReworked Pentateuch. Although these excerpts must be utilized with care, they can still be useful for the text critic. Finally, there are liturgical texts, such as phylacteries and mezuzot, which preserve passages from Deuteronomy. These texts constitute a witness to the text(s) of Deuteronomy in circulation in the Second Temple period.

Having made the claim in the article cited in footnote 1 that it is possible to produce an eclectic critical text of Deuteronomy, I have undertaken to do so in this sample edition of Deut 32:1-9. I chose this passage for a sample text because there were Qumran manuscripts that covered portions of it, it contains a well-known textual variant (32:8), and it is poetry, which brings its own set of challenges.

The manuscript evidence for the passage is as follows: the Masoretic text (here using Leningradensis); the Septuagint and its daughter versions; the Samaritan Pentateuch; 4QDeut ${ }^{\mathrm{b}}$, 4QDeut ${ }^{\mathrm{c}}$, 4QpaleoDeut ${ }^{\mathrm{r}}$, 4QDeut ${ }^{\mathrm{j}}$, and 4QDeut ${ }^{\mathrm{q}}{ }^{2}$ In the apparatus and text-critical commentary that follows I will

\footnotetext{
1) For the details of these manuscripts and the others mentioned in this article, and the passages from Deuteronomy which they contain, see S. W. Crawford, "Textual Criticism of the Book of Deuteronomy and the Oxford Hebrew Bible Project," in Seeking out the Wisdom of the Ancients: Essays Offered to Michael V. Fox on the Occasion of His Sixty-Fifth Birthday, eds. R. Troxel, K. Friebel and D. Magary (Winona Lake, 2005), pp. 315-326.

2) The bibliography is as follows: Biblia Hebraica Leningradensia, ed. A. Dotan (Peabody, 2001); The Old Testament in Syriac According to the Peshitta Version, Part 1, fascicle 2; Part II, fascicle 1b, Leviticus- Numbers-Deuteronomy-Joshua, eds. D. J. Lane, A. P. Hayman, W. M. van Vliet, J. H. Hospers, H. J. W. Drijvers, J. E. Erbes (Leiden, 1991); The Bible in Aramaic, ed. A. Sperber (3 vols.; 3rd impression; Leiden, 2004); Biblia Sacra iuxta Vulgatam Versionem, Tomus 1,
} 
guide the reader through the text-critical decisions behind the critical text as it is presented here.

The text as presented is laid out stichometrically, either by verse or halfverse. The most ancient manuscript evidence for this passage, 4QDeut ${ }^{\mathrm{c}}$ and 4QDeut ${ }^{\mathrm{q}}$, indicates that by the second century BCE the Song of Moses, of which these verses are a part, was arranged on the scroll stichometrically.

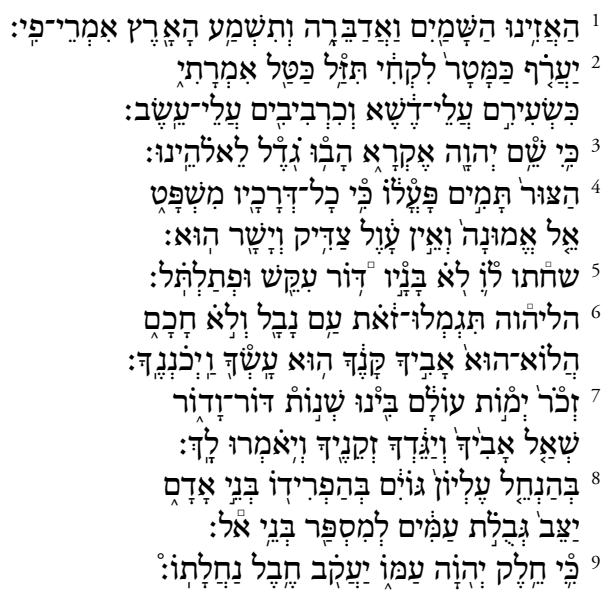

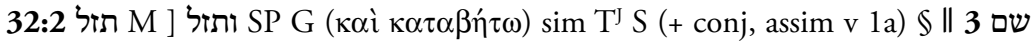

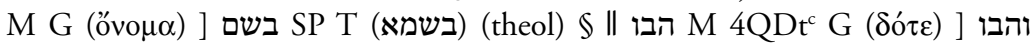

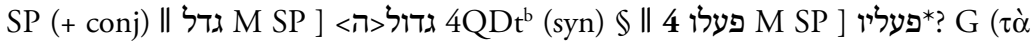

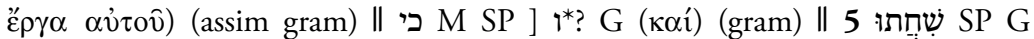

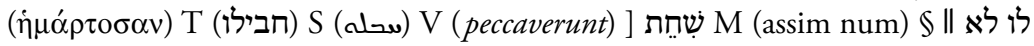

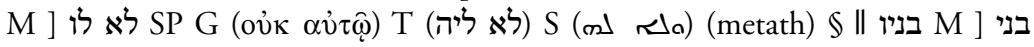

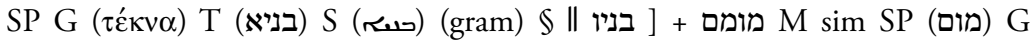

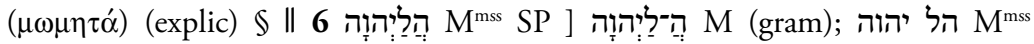

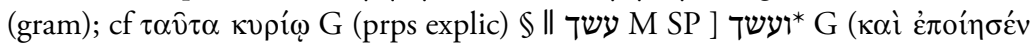

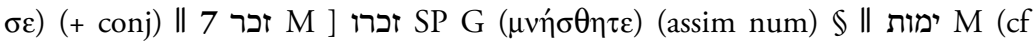

Genesis-Psalmi, ed. R. Weber (Stuttgart, 1983); Septuaginta, Vetus Testamentum Graecum, vol. III, 2, Deuteronomium, ed. J. Wevers (Göttingen, 1977); Jewish and Samaritan Version of the Pentateuch, eds. A. and R. Sadaqa (Tel Aviv, 1961); Qumran Cave 4, IX, Deuteronomy, Joshua, Judges, Kings, eds. E. Ulrich, F. M. Cross, S. W. Crawford, et al.(DJD XIV; Oxford, 1995); Qumran Cave 4, IV, Palaeo-Hebrew and Greek Biblical Manuscripts, eds. P. W. Skehan, E. Ulrich, J. Sanderson (DJD IX; Oxford, 1992). 


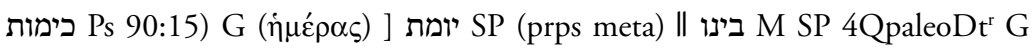

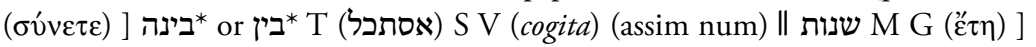

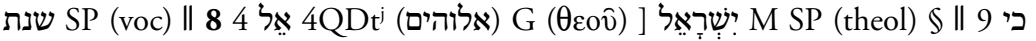

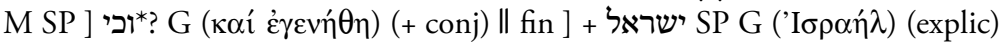

\section{Text-Critical Commentary}

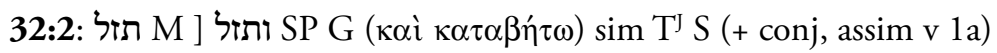

The textual history of Deuteronomy tends toward expansion, especially in the addition of the conjunction. This type of expansion also occurs in verses 3,6 , and 9 .

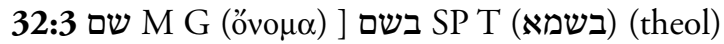

The addition of the preposition $ב$ in SP distances the speaker from the deity.

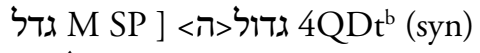

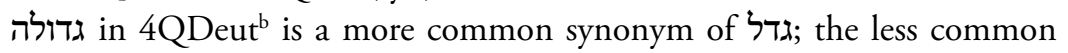
form is preferable.

32:4 The $G$ translation makes two theological changes from its Hebrew Vorlage, substituting השsós for הוא and אúpios for. The latter is also an explication.

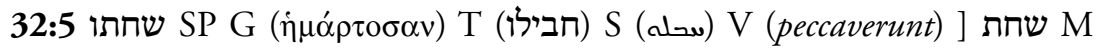
(assim num)

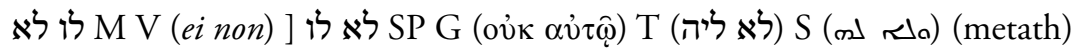

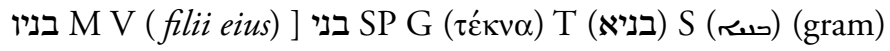

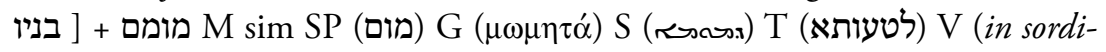
bus) (explic)

Verse 5 presents a text-critical challenge: its first clause is almost hopelessly corrupt. The reading of each version displays different errors and subsequent attempts to make sense of the result. M reads: שחת לו לא בניו מומם, literally "He has dealt corruptly with him, not his sons their blemish." G reads:

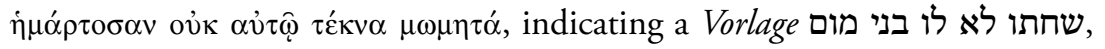
"They have sinned (dealt corruptly), not his, blemished children." SP also has שחתו לא לו בני מום, "They have dealt corruptly, not his, blemished children.” The minor versions attempt to make sense of this. The commentaries all make suggestions, reaching no consensus. The following examples give an indication of the variety of proposed solutions. 
Dillman proposes שחתו לו בניו מום בם, "His children have dealt corruptly towards him; there is a blemish in them." ${ }^{3}$ He has chosen the plural verb of G and SP. Deciding that לא לו, in whatever order, is a dittography, he chooses the preposition as a complement to the verb. Last, he tries to sort out the corruption at the end of the phrase by positing the loss of waw on the end of בני in G and SP, and the loss of a bet in all three versions, with subsequent loss of mem in G and SP.

Tigay suggests two possibilities: ${ }^{4}$

1. שחתו לו בניו אמן במן "His children violate against him loyalty."

2. שחתו לוא בניו אמן במן "His non-children violated loyalty." Both these possibilities posit an aleph-mem confusion, with further corruption, including dittography.

Craigie offers an imaginative reconstruction: ${ }^{5}$

שחתו לו לאבני מרמה gests that "stones" as a metaphor for Israel contrasts with "Rock" in verse 4 as a metaphor for God.

I have adopted the reading suggested here-שנחתו לו לא בניו-for the following reasons, the order of which is important. The phrase לא לא בניא, "not-my-

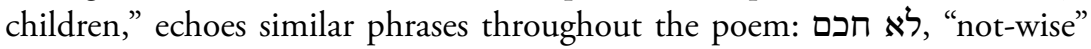
(v. 6), לא אלה אל לא לא, "not-a-god" (v. 17), and" (v. 21). Once that phrase is retained, the verb must be plural (שחתו); the singular of $M$ is assimilation to other singular verbs nearby (e.g. v. 7) or is a case of haplography. Since לא בניו לו לא is a "frozen phrase," the order be correct; the order לא לא displayed by SP G T S is the result of metathesis. Finally, the word מום or a form thereof is an explicating plus added to clarify the corruption; once it was added the construct phrase בני מום (SP G S) crept in, brought about by loss of $\mathrm{i}$ by haplography (perhaps), then retained because it made better grammatical sense. There is, however, no versional support for the omission of מום.

\footnotetext{
3) As quoted by S. R. Driver, Deuteronomy (ICC; 3rd ed.; Edinburgh, 1902), p. 352.

4) J. Tigay, Deuteronomy (JPS Torah Commentary; Philadelphia/Jerusalem, 1996), p. 301.

5) P. Craigie, The Book of Deuteronomy (NICOT; Grand Rapids, 1976), p. 377, n. 15.
} 


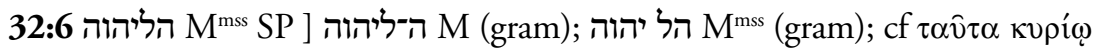
$\mathrm{G}$ (prps explic)

Verse 6 presents differences in letter spacing; I have selected the one that represents ancient practice.

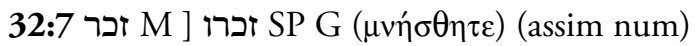

In verse 7 we have a difference in number in the verb in the various versions; the singular and plural alternate throughout this passage, and in this case I have retained the reading of the copy-text, suggesting that the secondary reading is by assimilation. ${ }^{6}$

\section{2:8 4QDt' (אלוהים) G (Acov̂) ] ישראל M SP (theol)}

In 1954 Patrick Skehan revealed בני אלהים as a Hebrew variant found at Qumran in 4QDeut' (the correct reading is בני אלוהים), and suggested that this reading was the probable Vorlage for the Septuagint variant. ${ }^{7}$ The reading given here, בני אל, while not occurring in any extant Hebrew witness, is preferred as making the best sense of the evidence. My reconstruction of what took place in the transmission of the text, resulting in the present variants, is בני אל as follows. First, the G reading, vî̄v $\theta \varepsilon \circ \hat{v}$, may be retroverted as either or בני אל(ו)הים (= 4QDeut'). If the former is chosen, then it is easy to suppose that the Vorlage of M SP, wishing to change a polytheistic text to monotheistic orthodoxy, inserted the consonants ישר before אל מלומים, thus creating the reading בני ישראל. Finally, 4QDeut's אלוהים is simply a scribal change, employing the more common term for "God."

\section{1 Kings 11:1-8}

$$
\begin{aligned}
& \text { Edition } \mathrm{A}(\approx \mathrm{M})
\end{aligned}
$$

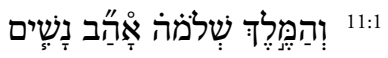$$
\text { Edition } \mathrm{B}(\approx \mathrm{G})
$$

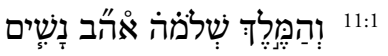$$
\text { (3) }
$$

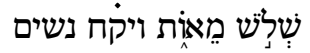

\footnotetext{
6) For the concept of "copy-text," see the accompanying article by R. Hendel, "The Oxford Hebrew Bible: Prologue to a New Critical Edition," part IV.

7) P. Skehan, "A Fragment of the 'Song of Moses' (Deut. 32) from Qumran," BASOR 136 (1954), pp. 12-15.
} 


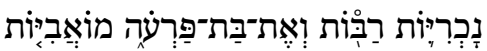

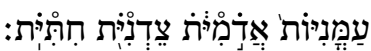

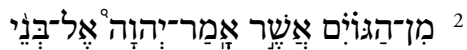

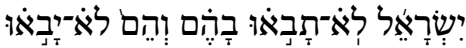

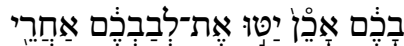

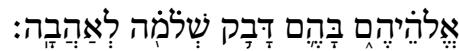

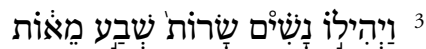

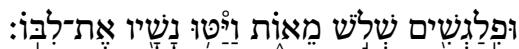

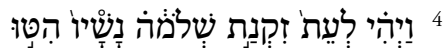

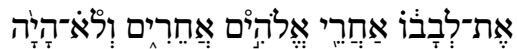

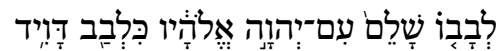

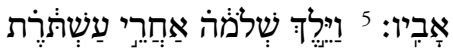

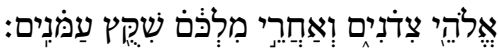

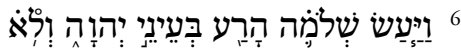

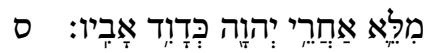

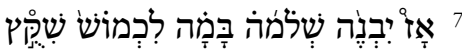

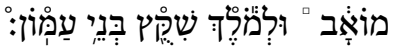

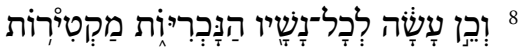

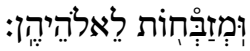

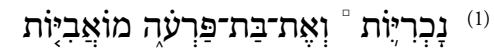

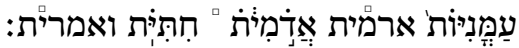

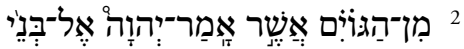

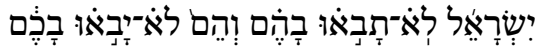

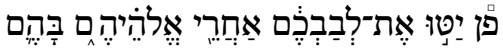

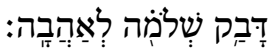

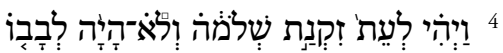

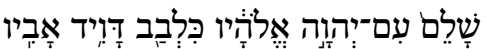

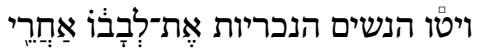

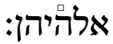

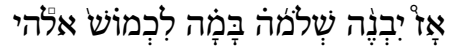

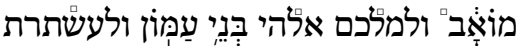

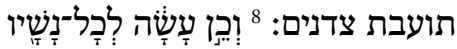

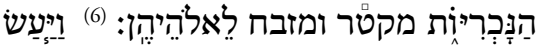

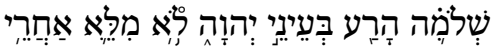

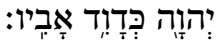

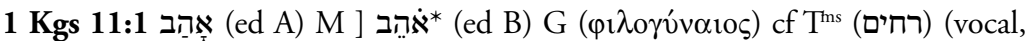

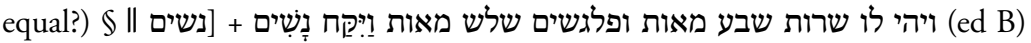

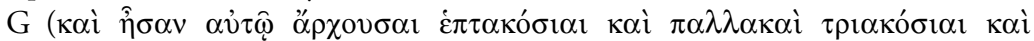

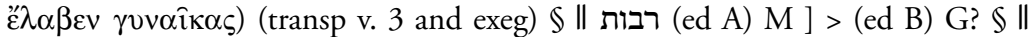

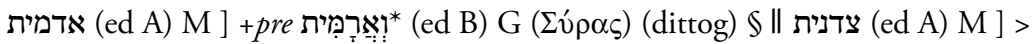

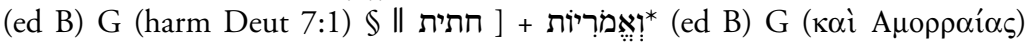

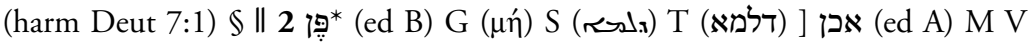
(certissimo enim) (mod?) $\$ \| 3 \approx$ (3) (transp ed B, see sub v 1) || שרות ] +pre נשים M (> G) (explic) \$ ויטו נשיו את לבו (ed A) M ] > (ed B) G (exeg)

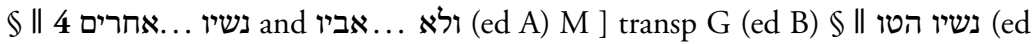

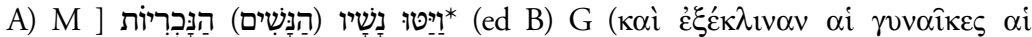

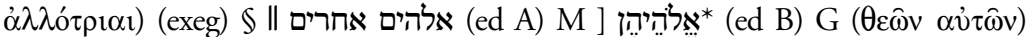

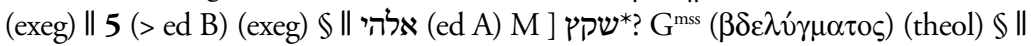




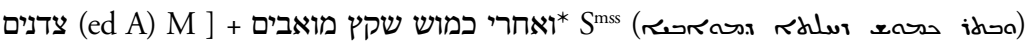

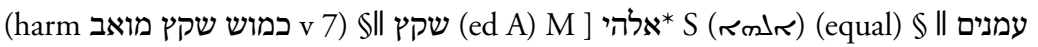

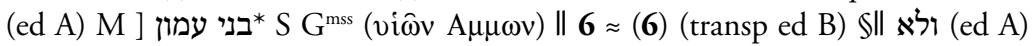

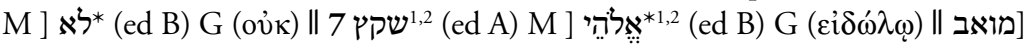

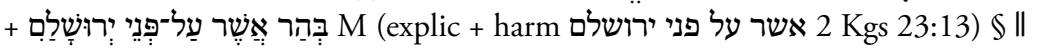

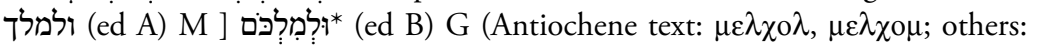

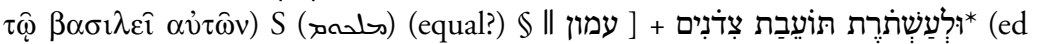

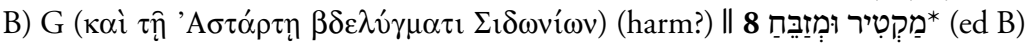

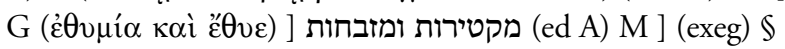

\section{Text-Critical Commentary}

The divergences between the Septuagint on the one hand, the MT and the other versions on the other hand, point to the existence of two distinct Hebrew editions of 1 Kings. It is not easy to determine which edition precedes the other. On the whole, $M$ reflects an older stage than $G$, but there are many details where the relation seems to be the reverse. After the two editions branched off from one another, each one of them continued to be altered by scribes. ${ }^{8}$

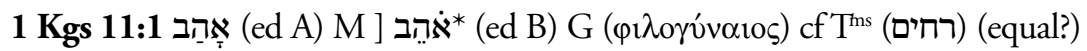

While M states that Solomon loved many foreign women, G says he was a "lover of women". Each reading fits its own context well, M proceeding to enumerate the foreign nations among which Solomon took wives, and $G$ leading on to the information that $S$. had many wives.

The vocalization of the form as a participle in edition B is uncertain. One manuscript of Targum Jonathan vocalizes the form רחים, corresponding to אהב, as a participle (all other manuscripts vocalize as a perfect, in accord with $\mathrm{M}$ ). The possible agreement of $\mathrm{G}$ with a $\mathrm{T}$ manuscript may be due to polygenesis.

8) The bibliography is as follows:

D. Barthélemy, Critique textuelle de l'Ancien Testament, I Josué, Juges, Ruth, Samuel, Rois, Chroniques, Esdras, Néhémie, Esther (OBO 50/1; Fribourg-Göttingen, 1982).

C. F. Burney, Notes on the Hebrew Text of the Books of Kings (Oxford, 1903).

J. A. Montgomery and H. S. Gehman, The Book of Kings (ICC; Edinburgh, 1950).

A. Schenker, Septante et Texte Massorétique dans l'histoire la plus ancienne du texte de 1 Rois 2-14 (CahRB 48; Paris, 2000).

Z. Talshir, "1 Kings and 3 Kingdoms-Origin and Revision. Case Study: The Sins of Solomon (1 Kgs 11)”, Textus 21 (2002), pp. 71-105. 
(ed B) G

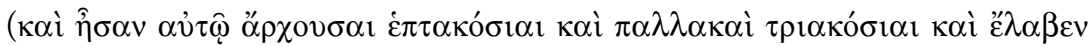

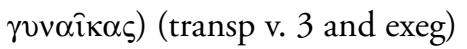

Edition B separates the issue of having many wives from that of marrying foreign women, by introducing into verse 1 the information on the high number of Solomon's wives and concubines. In edition A, this information comes in verse 3, suggesting that all Solomon's wives were foreign. Edition A does not separate the issues of many wives and foreign wives. Edition B is more rational than edition A on this point. Nevertheless, the Wiederaufnabme by means of the words ויקח נשים, which are lacking in edition A, suggests that edition B is secondary. Edition A is a mess, edition B an unsuccessful attempt to clean it up.

רבות (ed A) M ] > (ed B) G?

The absence of the adjective רבות, "many", in G may reflect the earliest stage of the text. It is easier to imagine that the word was added by a later scribe to edition A than to explain why it was omitted in edition B. Possibly,

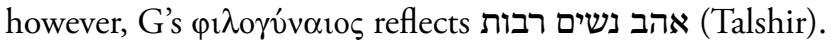

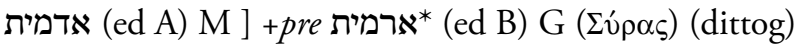

The addition of "Aramaic (women)" in G probably reflects a duplication of the word אדמית, "Edomite (women)."

צדנית (ed A) M ] > (ed B) G (harm Deut 7:1)

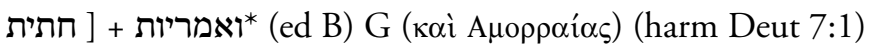

With the omission of the Phoenicians and the addition of the Amorites, the list of forbidden nations is to some extent realigned with the prescription in the Torah (Deut 7:1). In Ezra 9:1 and Neh 13:1-3, 23 the interdiction of intermarriage is extended from the seven Canaanite nations to include other foreigners.

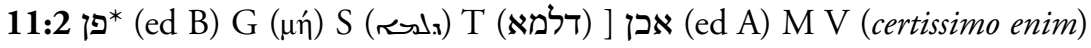
(mod?)

The use of אכן in M, confirmed only by V (certissimo enim), is suspect, since the particle elsewhere invariably introduces statements that are contrary to expectation. If $G, S$ and $T$ do indeed reflect a Hebrew text reading פן, this may be the original. Note that פן appears to have been edited out also in 2 Kgs 18:32, as a comparison with the parallel in Isa 36:17-18 will show. The reason for these changes may perhaps be found in the history of the 
Hebrew language. In Late Biblical Hebrew, פן is practically unattested (exception: 1 Chr 10:4, taken over from 1 Sam 31:4). In Qumran and Ben Sira, פi is used, as a classicism, in specific text types only.

In this verse the masculine suffixes of $M$ are rendered by feminine pronouns in some of the versions (Antiochene Septuagint, Peshitta, Vulgate). This is not a matter of text, but of exegesis.

\section{1:3 נשים M (> G) (explic)}

The absence of the word "wives" in G may again reflect the earlier stage of the text, as it is easier to explain its later addition in edition A than its omission in edition B (or in the process of translation).

ויטו נשיו את לבו (ed A) M ] > (ed B) G (exeg)

Edition A is very repetitive, with the formula ילבי + לבר + suffix reiterated three times (verses 2, 3 and 4). The alleviation of this threefold repetition by the omission of the phrase in verse 3 (verse 1 in edition B) in G may go back to edition $\mathrm{B}$.

\section{1:4 ולא ... אביו and A) M ] transp G (ed B)}

It is not impossible that edition B originally omitted the clause "and his heart was not perfect withYhwh his God, as was the heart of David his father" from this verse, relocating it, as a proper conclusion to the section on Solomon's sins, after verse 10 (see there). The clause may then have been restored to the present verse under the influence of edition A, while ending up in a slightly different position within the verse. There is, however, no manuscript evidence for this scenario.

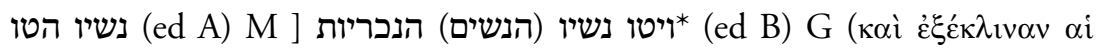

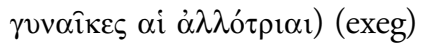

The addition of the word "foreign" in edition B coheres with the distinction of the two issues in verse 1 discussed above. It shows the attention of the editor to the logical flow of the text. It also reveals the secondary nature of edition B. If the word הנכריות was present in the original text it is hard to explain why edition A omitted it.

11:5 The entire verse is omitted in edition B, probably because it was felt to add nothing to what was told in verses 7-8. 


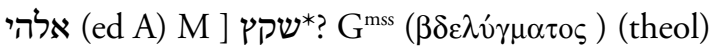

A theological correction is here reflected in the Antiochene Greek, which supplements the text of verse 5 on the basis of a Hebrew text. The variant in the Antiochene text is typologically later than the text of edition A (dysphemism). See below on a similar variation between $M$ and $S$ in this same verse.

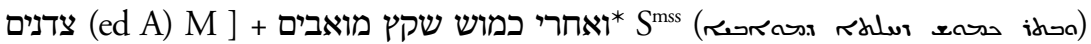

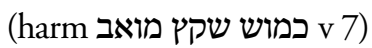

The majority text of the Peshitta adds a third divinity, harmonizing with verse 7 . The secondary nature of the addition is demonstrated by its absence in ms 9a1. Where this manuscript is closer to $M$ than the other Peshitta manuscripts it usually reflects the original Syriac text (see M. Weitzman, "The Originality of Unique Readings in Peshitta MS. 9a1," in The Peshitta: Its Early Text and History, eds. P. B. Dirksen and M. J. Mulder [Leiden, 1988], pp. 225-258).

שקץ (ed A) M ] אלהי) S (אלח (equal)

$\mathrm{M}$ is typologically later than the text reflected in $\mathrm{S}$ (dysphemism). Whether this means $S$ preserves the older text is a different question, however. Once the equivalence between the terms "abomination" and "god", when applied to gods of other nations, was established, scribes may have been led to change the text either way. From the point of view of textual history, the readings are equally valid (equal).

11:6 In edition $B$ the verse follows verses 7 and 8 of edition $A$.

אשר על פני ירושלם M (explic + harm 2 בהר אשר על פני ירושלם + [ מואב 11:7) Kgs 23:13)

The absence of these words from edition B are hard to explain if they formed part of the original text. It is better, therefore, to suppose they were added in the $\mathrm{M}$ tradition (including S T V) on the basis of $2 \mathrm{Kgs}$ 23:13.

מלקף (ed A) M ] מלכם (ed B) G (Antiochene text: $\mu \varepsilon \lambda \chi o \lambda, \mu \varepsilon \lambda \chi o \mu$; others: $\tau \hat{\emptyset}$ $\beta \alpha \sigma \imath \lambda \varepsilon \hat{\imath} \alpha \hat{v} \tau \hat{\omega} v) S$ (sol) (equal?)

Apart from this verse, the god of the Ammonites is always called Milkom in the Bible. The absence of mimation in the present verse may be due to a mistake or it may reflect an early variant form of this divine name. 


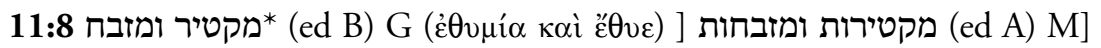
(exeg)

On purely internal grounds one should have to say the Antiochene Text here represents the Old Greek, and the Old Greek the original text of the passage. One understands that a text accusing King Solomon of active idolatry should have been attenuated by later scribes, but the reverse development is hard to envisage. The Antiochene text is a narrow basis, however, for constructing the correct Hebrew text.

III. Jeremiah 27:1-10 (34 G)

Edition $A(\approx G)$

27:[1]

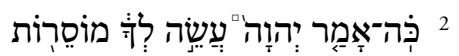

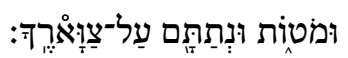

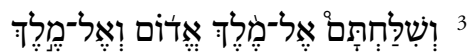

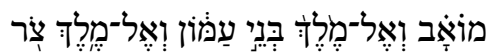

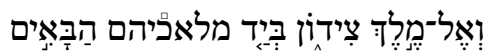

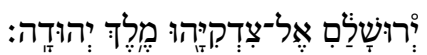

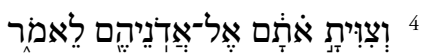

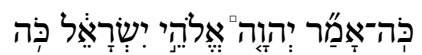

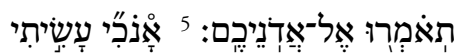

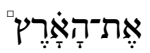

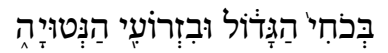

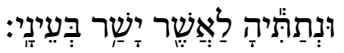
6

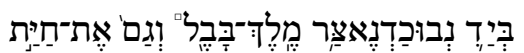

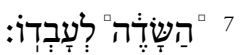

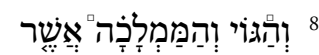

Edition B $(\approx \mathrm{M})$

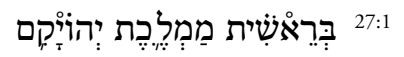

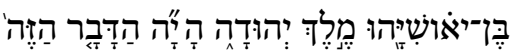

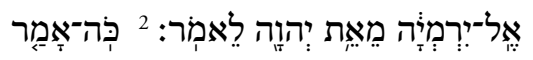

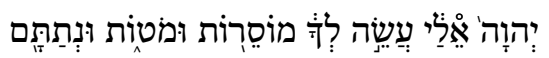

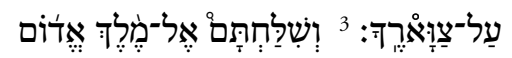

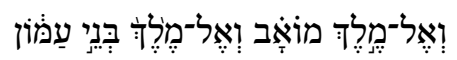

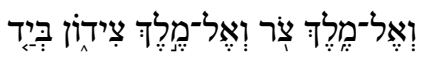

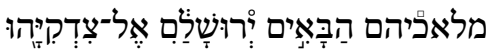

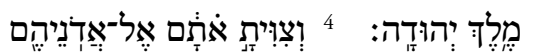

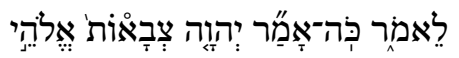

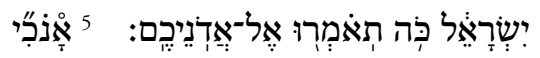

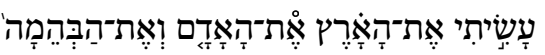

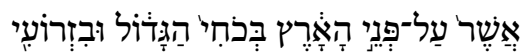

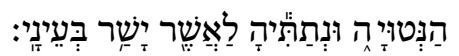

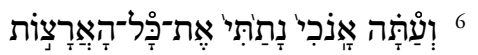

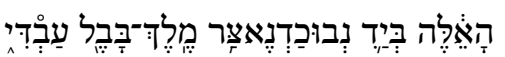

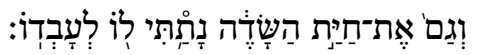

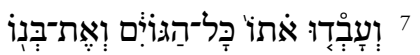

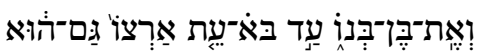

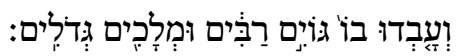

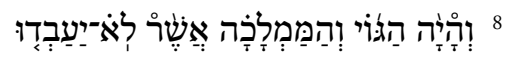




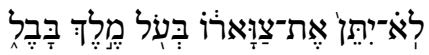

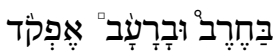

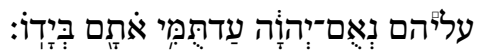
9

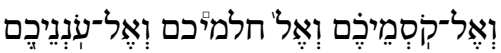

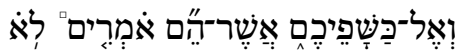

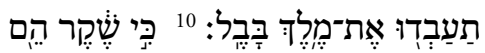

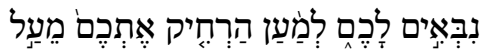

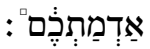

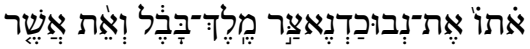

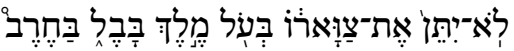

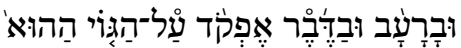

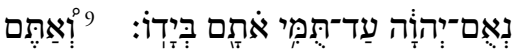

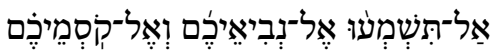

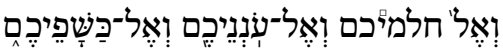

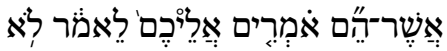

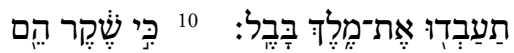

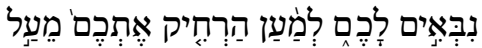

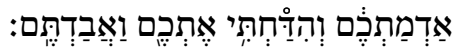

27(34 G):1 > ed A (add ed B, harm בראשית ממלכות יהויקים בן יאשיהו מלך יהודה

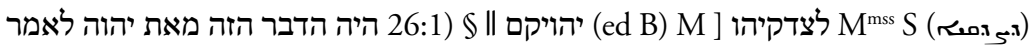

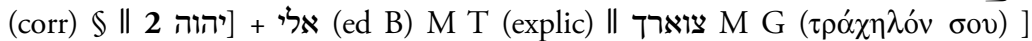

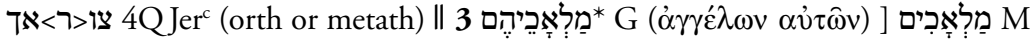

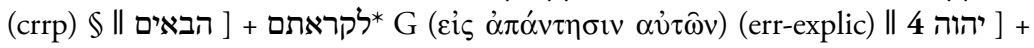

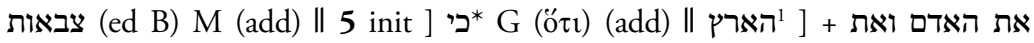

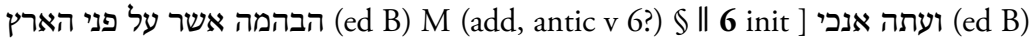

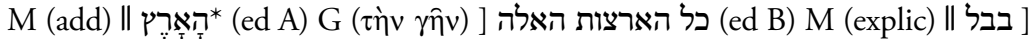

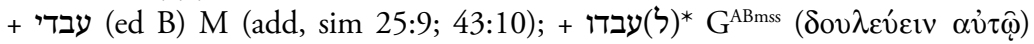
(harm v 6 fin $\$$ | נתתי לו + [ השדה (ed B) M (explic) \| 7 > ed A (add ed B)

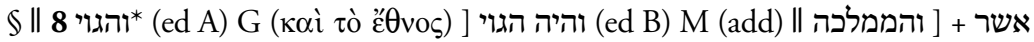

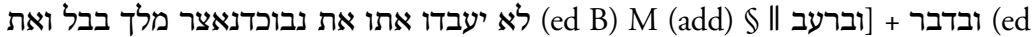

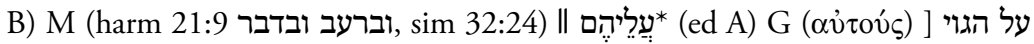

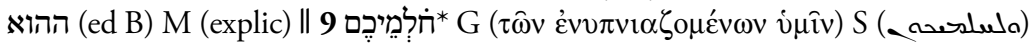
V (somniatores) [ אלמתכם (ed B (crrp) || אליכם לאמר + (explic) || 10

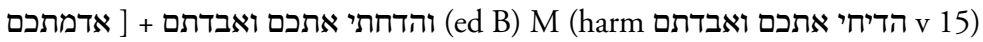

\section{Text-Critical Commentary}

As explained in the introduction, edition B is characterized by frequent additions sparked by a variety of principles, such as supplying additional information, expanding titles, inserting evolving traditions, attempting to make the text clearer, etc. Thus, whereas some individual ambiguous readings could be seen either as an omission in edition $\mathrm{A}$ or as an addition in edition $\mathrm{B}$, when the latter is as likely as the former, the general tendency weighs in favor of the latter (see on v 5 below). ${ }^{?}$

9) The bibliography is as follows: 


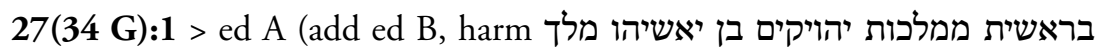
26:1) יהודה היה הדבר הזה מאת יהוה לאמר

Editor B has inserted at the beginning of this chapter, as he did in 7:1 and 16:1, an introduction not found in G; in fact, this historical setting is repeated from 26:1 in virtually identical words. But it is demonstrably incorrect, since in vv. 3 and 12 the king is Zedekiah (see next). Chapter 27, rather than being connected with ch. 26 , is to be connected with ch. 28 , which does center on Zedekiah.

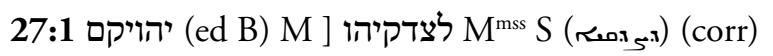

The incorrect name supplied in the introductory setting by editor B, in turn, caused some scribes in the M tradition subsequently to correct "Jehoiaqim" in v. 1 to "Zedekiah."

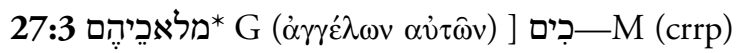

Both the odd syntax in M (מלאכים הבאים, vs. המלם) and the context (explicit mention of the kings) suggest "their messengers."

27:5 את האדם ואת הבהמה אשר על פני הארץ + [ 1'הארץ (ed B) M (add, antic $\mathrm{v} 6$ ?)

Whereas omission due to homoioteleuton הארץ ...הארץ is possible (Jensen, p. 118), the fem. sing. suffix (ונתתיה) indicates that the M reading is intrusive (so Holladay, p. 112), perhaps in anticipation of וגם את חית השדה in the next verse.

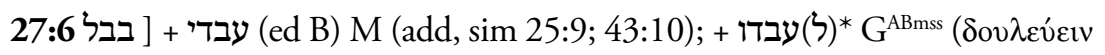
$\alpha \dot{\tau} \tau \hat{\text { ஸे) }}\left(\right.$ harm $\left.\vee 6^{\text {fin }}\right)$

The Hebrew Vorlage of the OG (= Gs Bo Aeth) did not contain עבדי. The B editor added עבדי, as he did in the only other two occurrences where

Bogaert, Pierre-Maurice, "La vetus latina de Jérémie: text très court, témoin de la plus ancienne Septante et d'une forme plus ancienne de l'hébreu (Jer 39 et 52)", in A. Schenker, ed., The Earliest Text of the Hebrew Bible: The Relationship between the Masoretic Text and the Hebrew Base of the Septuagint Reconsidered (SBLSCS 52; Atlanta, 2003), pp. 51-82.

William McKane, A Critical and Exegetical Commentary on Jeremiah (ICC; 2 vols.; Edinburgh, 1986, 1996).

Emanuel Tov, "Exegetical Notes on the Hebrew Vorlage of the Septuagint of Jeremiah 27 (34)", in idem, The Greek and Hebrew Bible: Collected Essays on the Septuagint (Leiden, 1999), pp. 315-31.

Emanuel Tov, "The Literary History of the Book of Jeremiah in Light of Its Textual History", in idem, The Greek and Hebrew Bible: Collected Essays on the Septuagint (Leiden, 1999), pp. 363-384. 
Nebuchadnezzar is called עבדי in Jeremiah (25:9; 43:10); the view that Nebuchadnezzar is God's עבד is a characteristic expansion of editor B, whereas G

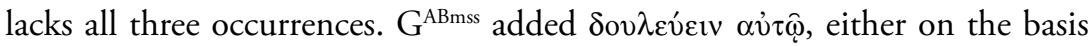
of an early Hebrew ms which had עבדי or by harmonization with לעבדו at

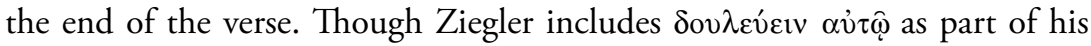
critical text, $G^{S}$ probably retains the preferable $O G$ reading while $G^{\text {ABmss }}$ is secondary. Note that Ziegler's characterization of $G^{S}$ concludes that "gewöhnlich ist ihre Lesart als ursprünglich anzunehmen” (pp. 50-51).

27:7 > ed A (add ed B)

The B edition adds: ועבדו אתו כל הגוים ואת בנו ואת בן בנו עד בא עת ארצו גם הוא ועבדו בו גוים רבים ומלכים גדלים. Unlike v. 5 where there was the possibility of homoioteleuton, v. 7 has no triggers for omission; here the B editor simply expands.

27:8 אשר לא יעבדו אתו את נבוכדנאצר מלך בבל ואת + [ והממלכה (ed B) M (add)

Again, although homoiarkton, אשר לא ... אשר לא, could possibly explain a loss of material, expansion by the B editor is more likely; note that the extra material adds explicit (though unnecessary) information with the king's name, and that the resumptive conjunction is ואת , whereas there was no in the preceding clause. 